\title{
MENINGKATKAN KEMAHIRAN MEMBACA HURUF HIJAIYAH MENGGUNAKAN MEDIA KARTU TUKAR HURUF PADA PEMBELAJARAN ALQURAN HADITS KELAS III MIN 21 KECAMATAN PAMINGGIR
}

\author{
${ }^{1}$ Syarifuddin, ${ }^{2}$ Nasrullah, ${ }^{3}$ Muhammad Syaiful \\ ${ }^{1}$ Sekolah Tinggi Ilmu Al-Quran, ${ }^{2}$ Madrasah Ibtidaiyah Negeri 21 Hulu Sungai Utara, \\ ${ }^{3}$ Universitas Nahdlatul ulama Kalimantan Selatan, Indonesia \\ Email: ${ }^{\text {Syarifuddin.stiq@gmail.com}}$ 를.tabasan@gmail.com, \\ syaifulmuhammad1702@gmail.com
}

Website : https://jurnal.uin-antasari.ac.id/index.php/ptkpend/index

Received: 26 Februari 2021; Accepted: 02 Juni 2021; Published: 14 Juni 2021

\begin{abstract}
This research was conducted to improve students' reading skills in hijaiyah letters in class III MIN 21 by using letter exchange cards as media. The type of this research is Classroom Action Research (PTK) with two cycles preceded by a pre-cycle to determine students' initial abilities before the application of letter card media. The sample used is a random class cluster. The subjects of this study were all students of class III MIN 21 with a total of 12 people. The assessment instruments used were in the form of non-tests and observation sheets. Based on the research, the results obtained: The pre-cycle mentions letters with the total number of students getting an average score of 50 and how to read by writing letters gets an average score of 45 with such results, the pre-cycle is stated that none of the students meet the criteria for completeness of the specified $70 \mathrm{KKM}$. After being given the media, the student's score card increased. In the first cycle I the results showed that there were 6 students who had completed the specified KKM with the average score of all students was 66.7. The results of the second cycle II showed satisfactory results with student completeness reaching 12 people with an average score of 85 . Based on the data analysis, it was concluded that the use of letter exchange card media could increase students' proficiency in reading hijaiyah letters.
\end{abstract}

Keywords:Card media; Hijaiyah letters; Al-Quran Hadith

\begin{abstract}
ABSTRAK
Penelitian ini dilakukan untuk meningkatkan kemahiran membaca huruf hijaiyah siswa pada kelas III MIN 21 dengan menggunakan media kartu tukar huruf. Jenis penelitian ini ialah Penelitian Tindakan Kelas (PTK) dengan dua kali siklus yang didahului pra siklus untuk mengetahui kemampuan awal siswa sebelum diterapkannya media kartu huruf. Sampel yang digunakan adalah cluster random class. Subjek penelitian ini adalah semua siswa kelas III MIN 21 dengan jumlah 12 orang. Intrumen penilainan yang digunakan adalah berbentuk non-tes dan lembar observasi. Berdasarkan penelitian diperoleh hasil: pra siklus menyebutkan huruf dengan jumlah siswa seluruhnya mendapatkan nilai rata-rata 50 dan cara membaca dengan mensukunkan huruf mendapat nilai rata-rata 45 dengan hasil demikian maka pra siklus dinyatakan tidak ada satupun siswa yang memenuhi kriteria ketuntasan dari $70 \mathrm{KKM}$ yang ditentukan. Setelah diberikan media kartu nilai siswa menjadi meningkat. Pada siklus pertama I hasilnya menunjukkan ada 6 orang siswa yang tuntas memenuhi KKM
\end{abstract}


yang ditentukan dengan rata-rata nilai dari semua siswa adalah 66,7. Hasil dari siklus kedua II menunjukkan hasil yang memuaskan dengan ketuntasan siswa mencapai 12 orang dengan nilai rata-rata 85 . Berdasarkan analisis data tersebut maka disimupulkan penggunaan media kartu tukar huruf dapat meningkatkan kemahiran siswa dalam membaca huruf hijaiyah.

Kata Kunci: Media kartu; Huruf Hijaiyah; Al-Quran Hadis

\section{PENDAHULUAN}

Sekolah merupakan bagian dari tempat pendidikan yang formal dan memiliki tujuan untuk mencetak generasi penerus bangsa yang lebih baik dengan ilmu dan pengetahuan. Pendidikan menjadi hal yang penting untuk dilaksanakan di setiap daerah bahkan bangsa dan negara, karena dengan pendidikan sebuah negara akan bisa berlangsung. Bisa dibayangkan apabila dalam sebuah bangsa atau negara tidak ada satupun masyarakatnya yang melanjutkan pendidikan, maka apa jadinya negara tersebut, tidak akan lagi bisa berlanjut, bahkan akan mengalami kehancuran karena tidak ada lagi orang yang akan memimpin negara tersebut.

Pendidikan harus menjadi prioritas utama, selain untuk menjamin keberlangsungan bangsa, juga untuk mengembangkan bangsa tersebut. Karena melalui pendidikan bukan hanya saja mengasah inteletualitas, tapi juga di dalam pendidikan harus mampu mengembangkan bakat menjadi lebih terampil.

Undang-undang No 20 tahun 2003 tentang Pendidikan Nasional, pasal 3 tentang fungsi dan tujuan yang menyatakan:

"Pendidikan Nasional berfungsi mengembangkan kemampuan dan membentuk watak serta peradaban bangsa yang bermanfaat dalam rangka mencerdaskan kehidupan bangsa, bertujuan untuk berkembangnya potensi. Peserta anak didik menjadi manusia yang beriman dan bertakwa kepada Tuhan Yang Maha Esa, berakhlak mulia, sehat, berilmu, cakap, kreatif, mandiri dan menjadi warga negara yang demokratis serta bertanggung jawab (Undang-
Undang RI Nomor 20 Tahun 2003, 2013, hlm. 6)"

Bentuk usaha yang bisa dilakukan untuk mendidik anak adalah dengan cara pengajaran, KH Dewantara sebagaimana dikutip A. Tafsir menyatakan bahwa pengajaran itu adalah salah satu bagian dari pendidikan, pengajaran tidak lain adalah pendidikan dengan cara memberikan ilmu atau pengetahuan serta kecakapan. (Tafsir, 2008, hlm. 7)

Pengajaran terlebih dahulu didahului dengan menyusun perencanaan pembelajaran karena bagian penting yang harus diperhatikan yang akan menentukan arah kemana kualitas pembelajaran secara menyeluruh dan menjadikan kualitas pembelajaran itu menjadi lebih baik serta meningkatkan sumber daya manusia menjadi lebih bermutu. Oleh karena itu bagaimanapun seorang guru harus pandai menyusun perencanaan pembelajaran. Mulyasa dalam bukunya menyatakan bahwa perencanaan pembelajaran atau yang disebut dengan lesson plan itu harus benar-benar dipersiapkan oleh seorang guru. Ia menyatakan bahwa lesson plan dalam kondisi dan situasi bagaimanapun guru tetap harus menyusun lesson plan karena perencanaan merupakan pedoman pembelajaran. (Mulyasa, 2009, hlm. 153) guru harus mampu membuat RPP untuk menjadikan acuan dalam melaksanakan KBM di kelas. Selain itu KBM juga harus memuat sasaran dan tujuan yang mencakup aspek kognitif, afektif dan psikomotorik yang tertuang dalam KBM.

Pelajaran Alquran Hadits merupakan pelajaran yang penting dalam pendidikan di Madrasah Ibtidaiyah. Untuk pembelajaran Alquran Hadits seorang guru juga harus membuat sebuah rencana pembelajaran sehingga dalam proses KBM guru dapat lebih siap dalam 
Jurnal PTK dan Pendidikan

Vol. 7, No. 1, Januari - Juni 2021 (16-26)

memberikan pelajaran kepada siswa. Pada pelajaran Alquran Hadits siswa diharapkan mampu untuk dapat membaca dan menulis huruf hijaiyah baik dari segi pengenalan huruf, pengenalan kata dan merangkai kata. Siswa yang belum mengenal huruf dengan baik, akan merasa kesulitan dalam merangkai kata dan menyambung kata-kata menjadi kalimat hijaiyah yang baik. kesulitan ini akan membawa dampak negatif bagi siswa itu sendiri.

Siswa yang belum mengenal katakata atau huruf-huruf hijaiyah pada kelas bawah dengan baik ia akan merasa cukup kesulitan pada kelas tinggi karena pada kelas tinggi sudah diajarkan berbagai ayat-ayat yang berkenaan dengan Alquran dan hadis-hadis nabi baik itu menghafal ayat atau menghafal surah atau menghafal hadits-hadits pendek pada pembelajaran Alquran Hadits.

Hal ini juga berdampak kepada kehidupan sehari-hari karena bacaanbacaan shalat yang harus dikerjakan oleh seorang muslim juga berbentuk dan terangkai dengan huruf-huruf hijaiyah. Oleh karena itu, berbagai upaya dilakukan untuk membantu siswa yang kesulitan dalam mengenali huruf, merangkai kata, mematikan akhir huruf (men-sukun-kan) kata-kata huruf hijaiyah dan lainnya yang berhubungan dengan membaca dan merangkai kata-kata huruf hijaiyah menjadi kalimat hijaiyah yang baik. Dalam penelitian ini, siswa kelas III dipilih oleh penulis dikarenakan siswa kelas III telah pandai dalam membaca huruf latin Bahasa Indonesia dan hal ini memberi kemudahan kepada siswa ketika diterapkan pembelajaran membaca hurufhuruf hijaiyah dengan media tukar kartu huruf. Hal ini juga dikarenakan penelitian ini menggunakan pendekatan Bahasa Indonesia, baik penggunaan huruf latin Bahasa Indonesia maupun kata-kata dalam bahasa Indonesia.

Kemahiran berbahasa merupakan bagian terpenting dalam kehidupan sehari-hari, bahasa tegas dan renyah yang disampaikan kepada orang lain, bisa berefek. Bahasa yang baik akan membuat informasi yang disampaikan mudah diterima oleh orang lain. Agar berbahasa menjadi baik harus melalui proses belajar, adapun keterampilan yang harus dikuasai dalam berbahasa ada 4 komponen. 1) Menyimak; tidak hanya berbicara menyimak merupakan kemahiran awal yang harus dimiliki oleh seseorang. 2) Berbicara; berbicara adalah menyampaikan sesuatu atau ide kepada seseorang atau lebih dengan lisan, baik melalui interaktif, semi-interaktif dan non interaktif. (Nulyati, 2011, hlm. 23) 3) Membaca; merupakan keterampilan yang digunakan untuk memperoleh sesuatu ide atau informasi yang terdapat dalam tulisan. 4) Menulis; menulis merupakan kemahiran yang paling tinggi tingkatannya dalam berbahasa. Melalui tulisan seseorang bisa menyampaikan informasi dengan bentuk tulisan yang sudah dikemas sedemikian rupa agar menjadi informasi yang bermanfaat, menulis juga bisa disebut kemahiran produksi. Karena mampu mengembangkan tulisan dan ide-ide lainnya. (Zulela, 2012, hlm. 5)

Dengan demikian, dari keempat kemahiran yang harus di miliki seseorang dalam berbahasa maka kemahiran membaca menjadi amat penting, karena membaca merupakan tonggak awal seseorang akan mendapatkan ilmu pengetahuan.

Kemahiran antar individu seringkali berbeda-beda, ada yang memiliki kelebihan dalam bidang akademik seperti cepat dalam menangkap pelajaran ada juga perlahan bahkan lambat. Ini merupakan fitrah dari manusia. Namun kemahiran ini bisa diasah dan ditingkatkan melalui latihan-latihan khusus dan bahkan setiap kemahiran dapat menghasilkan sesuatu yang menguntungkan.

Beberapa pandangan dari para ahli mengenai pengertian kemahiran sebagai berikut: (Nur Lailiyah, t.t., hlm. 9-10) 
Jurnal PTK dan Pendidikan

Vol. 7, No. 1, Januari - Juni 2021 (16-26)

1) Gordon mendefinisikan kemahiran adalah kemampuan untuk melakukan suatu pekerjaan dengan cara efisien, efektif dan tepat. Keterampilan ini menurut Gordon mengarah kepada kemampuan psikomotorik

2) Dunette mendefinisikan kemahiran adalah menumbuhkan kognitif yang diperoleh dari pelatihan atau pengalaman dalam melakukan tugas keseharian.

3) Iverson mendefinisikan kemahiran diperoleh tidak hanya dengan mengikuti pelatihan, akan tetapi juga memerlukan kemahiran dasar agar dapat menghasilkan sesuatu yang bernilai lebih.

4) Robbins mendefinisikan kemahiran menjadi 4 bagian: a) Basic literacy skill (keahlian Dasar; b) Technical skill (keahlian secara teknis; c) Interpersonal skill (keahlian secara perorangan; d) Problem solving (pemecahan masalah).

Berdasarkan beberapa teori di atas maka kemahiran adalah kemampuan yang dimiliki seseorang baik dalam mengoperasikan sesuatu, mengembangkan pengetahuan, pemecahan masalah yang diperoleh baik secara alami maupun dari hasil proses. Oleh sebab itu berdasarkan teori di atas maka dalam penelitian ini peneliti lebih cenderung kepada keterampilan yang menekankan pada keahlian dasar (Basic Literacy).

Kemahiran yang sangat urgen dimiliki oleh setiap orang adalah kemahiran membaca. Tarigan mendefinisikan bahwasanya membaca merupakan upaya yang dilaksanakan agar memperoleh pesan dari penulis melalui tulisan. (Guntur Tarigan, 2009, hlm. 7). Dalam bahasa asing Burns mendefinisikan "reading is a complex act that must be learned. It is also a means by which further learning takes place. In other words, a person learns to read and reads to learn" dalam artian bahwasanya membaca adalah bagian dari kegiatan yang komplek dipelajari dan bagian alat untuk pembelajaran lanjutan. (Burns, P. C dkk., 1984, hlm. 11). Dari berbagai definisi tersebut bisa di simpulkan bahwasanya membaca merupakan sebuah usaha untuk memahami makna dalam sebuah bahan tulisan.

Senada dengan hal itu, Daeng dkk juga mendefinisikan, membaca dan menyimak adalah kegiatan inti agar dapat memperoleh dan menguras informasi lebih, maka dengan banyaknya informasi yang sudah diperoleh tentunya akan mempermudah seseorang dalam berbicara dan menulis. (Daeng, 2011, hlm. 4)

Pemerolehan pemahaman agar menjadi maksimal maka ketika membaca harus melibatkan aktivitas mental. Membaca tidak saja hanya menggerakkan mata dari kiri kekanan, namun juga harus melibatkan aktivitas berpikir supaya bisa menerjemahkan makna dari tulisan. Harjasujana menuturkan bahwasanya membaca merupakan kemampuan yang kompleks. Pembaca tidak hanya memandangi lambang-lambang tertulis semata, melainkan berupaya memahami makna lambang-lambang tertulis tersebut. Menurut Rahim, membaca adalah aktivitas rumit yang melibatkan aktivitas visual, berpikir, psikolinguistik, dan meta kognitif(Rahim, 2008, hlm. 2). Membaca juga merupakan keterampilan yang lambat laun akan menjadi perilaku keseharian seseorang. Pembaca memiliki sikap tertentu, pada awal sebelum keterampilan membaca ini terbentuk.

Berbagai definisi yang telah dijelaskan di atas bisa kita tarik kesimpulan bahwasanya membaca merupakan aktivitas yang melibatkan kegiatan melibatkan indra penglihatan seperti visual, mampu berpikir, psikolinguistik dan meta kognitif yang merupakan bagian kompleks. tujuan dari membaca adalah untuk mendapatkan sebanyak mungkin informasi melalui tulisan, agar diperoleh berbagai pengetahuan. 
Jurnal PTK dan Pendidikan

Vol. 7, No. 1, Januari - Juni 2021 (16-26)

Kemahiran dasar yang harus dimiliki oleh seorang siswa agar bisa mengikuti kegiatan pembelajaran adalah membaca (Prastisi, 2009, hlm. 1). Agar tujuan membaca lebih maksimal, hendaknya sebelum membaca tanamkan AMBAK (apa manfaatnya bagiku) (Bagir \& dkk, 2018, hlm. 37) dengan demikian membaca menjadi sebuah kegiatan yang menyenangkan. Guru dalam tugasnya dikelas membantu para siswa untuk memahami teks dengan menciptakan pengalaman yang mengenalkan, memelihara atau memperluas pemahaman dari para siswa (Rahim, 2008, hlm. 6). Maka oleh sebab itu membaca merupakan kemahiran reseftif bahasa tulis, membaca bagian dari interaksi interaktif agar dapat memperoleh sebuah bahasan atau makna yang termuat dalam bahasa tertulis. Membaca sebagai suatu kegiatan yang dilakukan oleh pembaca supaya mendapat pesan yang diinformasikan dari penulis melalui media kata-kata atau bahasa tulis (Guntur Tarigan, 2009, hlm. 7).

Dengan demikian, bahwasanya kemahiran membaca merupakan aktivitas yang dikerjakan seseorang supaya mendapat informasi atau pesan yang sampaikan dari penulis dengan perantara media bahasa tulis.

Ada beberapa metode kemahiran dalam membaca yang bisa diaplikasikan sebagai berikut (Hendrawati, 2010): 1) Metode Eja digunakan untuk menganalkan huruf-huruf alfabetis; 2)

Metode Bunyi digunakan setelah mengenalkan huruf-huruf alfabetis dengan membendakan bunyi dari hurufhuruf alfabetis; 3) Metode Suku Kata digunakan untuk merangkai suku kata atau huruf-huruf alfabetis menjadi kata kemudian menjadi kalimat sederhana; dan 5) Metode kata digunakan untuk merangkai kata-kata menjadi sebuah kalimat panjang dan menjadi sebuah cerita.

Media dalam artian kata diambil dari bahasa latin dalam bentuk jamak adalah medium yang mempunyai arti
Syarifuddin, Nasrullah, Muhammad Syaiful

perantara/pengantar (Tim pengembang Ilmu Pendidikan Bagian II, 2007, hlm. 205), sedangkan pengertian secara harfiah media dalam bahasa latin adalah medius yang memiliki artian tengah, koma, perantara/pengantar pesan oleh pengirim kepada penerima (Azhari Arsyad, 2005, hlm. 3). Namun dalam artian lain media bisa juga maknai dengan manusia, koma, benda atau peristiwa yang memungkinkan siswa mendapat pengetahuan dan keterampilan (Bahri Djamarah \& Zain, 1995, hlm. 4).

Media memiliki artian sempit dan luas, dalam artian sempit media hanya digunakan dilingkungan sekolah dengan cara efektif dalam pembelajaran. Adapun dalam artian luasnya media tidak hanya meliputi media elektronik yang kompleks namun juga melingkupi alat-alat sederhana misalnya fotografi, diagram, bagan yang dibuat oleh guru, objek nyata serta study banding/outbound ke luar sekolah juga disebut media, dan dalam hal ini guru menjadi media penyaji, radio dan televisi karena sama-sama memerlukan waktu untuk menyampaikan informasi kepada para siswa, tugas lain guru sebagai media adalah menyusun RPP melaksanakan penelitian (Hamalik, 2008, hlm. 202).

Dengan demikian, dari berbagai pendapat di atas dapat diambil kesimpulan bahwa media merupakan suatu alat bantu yang tak terbatas dan dapat digunakan sebagai penghubung pesan agar tercapai tujuan pembelajaran.

Di era 4.0 yang semakin canggih ini media pembelajaran sudah jauh lebih berkembang dari era-era sebelumnya baik itu dari jenis, daya input dan bahan, serta cara pembuatan. Adapun beberapa media yang berkembang adalah sebagai berikut: 1) Media audio merupakan media yang bisa didapat dari radio, kaset, recorder, piringan hitam dan lain-lain 2) Media visual merupakan media yang dapat digunakan melalui panca indra mata dengan menampilkan gambar, foto, lukisan dan lain-lain 3) Media Audio 
Jurnal PTK dan Pendidikan

Vol. 7, No. 1, Januari - Juni 2021 (16-26)

Visual merupakan gabungan dari panca indra pendengaran telinga dan panca indra mata penglihatan dengan menampilkan unsur suara dan gambar

\section{a. Pengertian Media Kartu Huruf}

Kartu huruf merupakan potonganpotongan karton atau kertas yang didalamnya terdapat huruf-huruf untuk mencapai tujuan pembelajaran (Azhar Arsyad, 2003, hlm. 77). Media kartu dengan padanan warna-warni digunakan agar bisa meningkatkan motivasi dalam meningkatkan kemahiran membaca huruf hijaiyah.

Media kartu termasuk alat permainan yang disukai anak-anak seperti yang diciptakan oleh para ahli diantaranya Maria Montessori, George Cruissepaire, Peabodi dan Froebet (Zaman dkk., 2008, hlm. 43).

\section{b. Langkah-langkah Penerapan Media Kartu Huruf}

Untuk menggunakan media kartu huruf digunakan langkah-langkah sebagai berikut: 1) Guru menyampaikan cara penggunaan kartu tukar huruf kepada siswa; 2) Siswa diberi potongan kartu tukar huruf dari karton berwarna yang berisi tulisan huruf hijaiyah dan huruf latin dengan Bahasa Indonesia; 3) Siswa diminta untuk membaca huruf hijaiyah yang ada pada kartu tersebut dan disebelah bagian tersebut terdapat huruf latin untuk cara membacanya; 4) Siswa menganti/ menukar huruf hijaiyah tersebut dengan huruf latin dari Bahasa Indonesia; 5) Setelah itu siswa diminta membaca huruf hijaiyah sesuai dengan huruf yang di milikinya dengan menggantinya menjadi huruf latin yang terdapat di samping/di belakang kartu huruf hijaiyah.

\section{c. Kelebihan dan Kekurangan Media Kartu Huruf}

Setiap media tentu memiliki kelebihan dan kekurangan tersendiri, kelebihan dari media kartu huruf sebagai berikut: 1) menambah gairah siswa untuk belajar; 2) menambah motivasi siswa dalam belajar 3) bahan mudah dibuat dan dicari; 4) mampu meningkatkan hasil belajar; 5) ketuntasan belajar materi yang sudah diterima mudah diingat; 6) pelajaran menjadi menarik.

Adapun beberapa kelemahan dari media kartu huruf adalah sebagai berikut: 1) suasana kelas menjadi kurang kondusif; 2) sering kelebihan waktu dalam memberikan materi; dan 3) media cepat rusak.

\section{d. Huruf-huruf Hijaiyah}

1) Pengertian Huruf Hijaiyah

Huruf hijaiyah adalah kumpulan huruf-huruf arab dengan jumlah 29 huruf yang digunakan di dalam AlQur'an(Syarbini \& Mufidah, 2010, hlm. 2). Hurufnya adalah sebagai berikut:

$$
\begin{aligned}
& \text { ا ب ت ث ج ح خ د ذ ر ز س ش ص ض ض }
\end{aligned}
$$

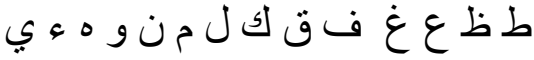

2) Transtliterasi Huruf hijaiyah

Transliterasi Huruf hijaiyah adalah suatu upaya untuk penyalinan huruf abjad dari bahasa arab ke huruf abjad bahasa lain. Tujuan utama transliterasi ini adalah untuk menampilkan kata-kata asal yang seringkali tersembunyi oleh metode pelafalan bunyi atau tajwid dalam bahasa arab.

Selain itu transliterasi juga memberi pedoman kepada para pembaca agar terhindar dari salah lafal yang bisa meyebabkan kesalahan dalam memahami makna asli kata-kata tertentu. Dalam bahasa arab, salah makna akibat salah lafal sering sekali terjadi karena tidak semua hurufnya dapat dipadankan dengan huruf-huruf latin. Karenanya kita terpaksa menggunakan konsonan rangkap ( ts, kh, dz, sy, sh, dh, th, zh, dan, gh ) dan tambah simbol lain ( h,-'-,-'- ), kesulitan ini masih ditambah lagi dengan proses pelafalan huruf yang memang banyak berbeda dan 
Jurnal PTK dan Pendidikan

Vol. 7, No. 1, Januari - Juni 2021 (16-26)

terdapat huruf-huruf yang harus dibaca secara panjang $(\mathrm{mad})$.

\section{METODE PENELITIAN}

Penelitian ini merupakan penelitian tindakan kelas (PTK) yang dilakukan dalam 2 siklus. Penelitian yang dilakukan oleh guru bersama kolaboratif (guru, kepala sekolah, peneliti) di dalam kelas untuk memperbaiki kinerja guru, yang nantinya akan meningkatkan hasil belajar siswa(Ansori, 2007, hlm. 4). Peneliti menggunakan model penelitian tindakan kelas yang diperkenalkan oleh Kurt Lewin.(Trianto, 2011, hlm. 29-30).

Penelitian ini dilakukan di MIN 21 Hulu Sungai Utara yang beralamatkan di Desa Bararawa Rt III No. 85 Kec. Paminggir Kab. Hulu Sungai Utara. Sampel yang digunakan dalam penelitian tindakan kelas ialah Cluster random class(Syarifuddin, 2019, hlm. 57) diambil dari kelas III dengan jumlah 12 siswa.

\section{HASIL DAN PEMBAHASAN}

Berdasarkan paparan data yang diperoleh dari hasil dari observasi siklus I dan II maka akan diuraikan sebagai berikut

1. Perbandingan Hasil Observasi Kegiatan Guru dalam Pembelajaran

Data hasil observasi kegiatan guru pada siklus I dan siklus II dapat dilihat dalam tabel berikut:

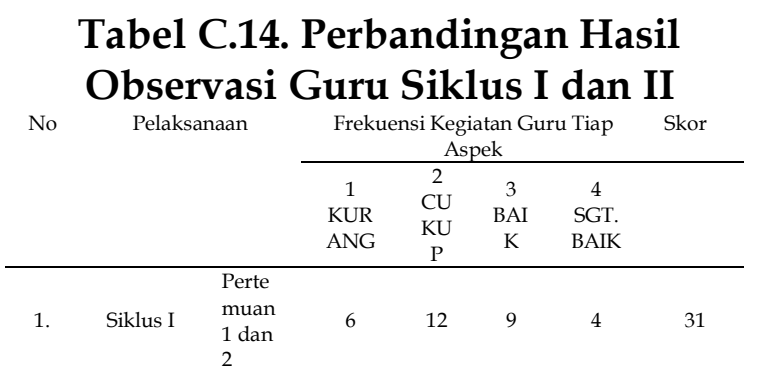

Syarifuddin, Nasrullah, Muhammad Syaiful

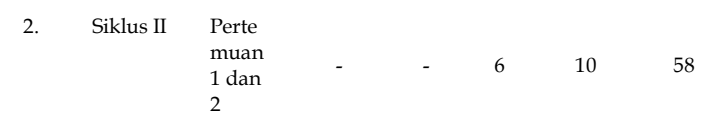

Tabel di atas menggambarkan peningkatan skor kegiatan guru dalam setiap siklus, siklus I skornya mencapai 31, siklus II mencapai 58, skor kegiatan guru dari siklus I hingga siklus II meningkat 27 poin.

Data yang terdapat pada tabel di atas memperlihatkan kenaikan yang signifikan pada kegiatan yang dilakukan oleh guru dalam pelaksanaan pembelajaran, hal ini dipengaruhi oleh beberapa faktor seperti meningkatnya pengetahuan guru tentang teknik-teknik mengajar, dan guru lebih menguasai materi, skenario serta rencana pembelajaran, sehingga apa yang menjadi kekurangan pada siklus I dapat dijadikan pelajaran oleh guru untuk perbaikan pada siklus II.

Perbaikan kegiatan guru dalam mengajar tidak lepas dari peran guru untuk menciptakan suasana yang menyenangkan di dalam kelas, sebagaimana dijelaskan bahwa guru memiliki 4 peran dalam pembelajaran(Gintings, 2010, hlm. 1415) yaitu 1) merencanakan kegiatan belajar dan pembelajaran; 2) menyiapkan kegiatan belajar dan pembelajaran; 3) menyelenggarakan kegiatan belajar dan pembelajaran; dan 4) mengevaluasi hasil belajara dan pembelajaran. Sebagaimana yang juga diterangkan oleh oleh Doyle yang dikutip oleh Sudarwan Danim(Afifuddin, 2017) mengungkapkan ada dua peran guru di dalam pembelajaran adalah guru harus dapat menciptakan keteraturan dan guru harus mampu menjadi fasilitator dalam proses pembelajaran. Keteraturan yang dimaksud dalam 
hal ini adalah yang terlibat langsung dan tidak langsung dalam proses pembelajaran misalnya tempat duduk siswa, kondusif saat pemeblajaran dikelas, sosialisasi antara siswa, sosialisasi siswa dengan pengajar, on time waktu masuk dan keluar, mengelola sumber belajar, bahan ajar, sistem dan aktivitas yang mendukung tercapainya kegiatan belajar, lingkungan yang kondusif dan sebagainya.

Tidak hanya itu saja guru harus memiliki kemampuan kompetensi pedagogis(Syarifuddin, 2017) seperti 1) Pemahaman wawasan dan landasan kependidikan; 2) Pemahaman terhadap peserta didik; 3) memiliki pengetahuan terhadap kurikulum; 4) Merancang pembelajaran; 5) melaksanakan pendidikan yang mendidik dan dialogis; 6) memanfaatkan teknologi; 7) menguasai teknik evaluasi. Dalam hal ini guru sudah mampu melihat kondisi peserta didik sehingga pada siklus II guru dapat lebih memberikan pelajaran dengan menyesuaikan kebutuhan siswa. Menurut Duffy dan Roehler(Eko Yulianto, t.t.) bahwasanya yang termasuk tugas guru adalah membuat kegiatan belajar mengajar menjadi lancar, bermoral dan menjadikan siswa merasa betah untuk belajar serta dapat menerapkan kurikulum.

2. Perbandingan Hasil Observasi Siswa Aktivitas Siswa Dalam Pembelajaran

Perbandingan hasil observasi aktivitas siswa pada siklus I dan siklus II dapat dilihat pada tabel dan grafik berikut:
Tabel C.15. Perbandingan Observasi Aktivitas Siswa dalam

Pembelajaran Siklus I dan II

\begin{tabular}{|c|c|c|c|c|c|c|}
\hline \multirow{2}{*}{ No } & \multirow{2}{*}{\multicolumn{2}{|c|}{ Pelaksanaan }} & \multicolumn{4}{|c|}{$\begin{array}{c}\text { Tingkat Aktivitas Siswa dalam } \\
\text { Pembelajaran }\end{array}$} \\
\hline & & & Kuran & Cuku & & \\
\hline 1 & & & & & & \\
\hline & Siklus I & $\begin{array}{l}\text { Pertemu } \\
\text { an } 1\end{array}$ & $0 \%$ & $50 \%$ & $50 \%$ & $0 \%$ \\
\hline 2 & Siklus II & $\begin{array}{l}\text { Pertemu } \\
\text { an } 1\end{array}$ & $0 \%$ & $0 \%$ & $8,7 \%$ & $91,3 \%$ \\
\hline
\end{tabular}

Dari tabel di atas dapat dijelaskan bahwa tingkat aktivitas siswa pada siklus I dan II mengalami peningkatan pada kriteria kurang aktif dan cukup aktif dengan selisih $25 \%$ dan pada siklus II dari kriteria aktif dengan persentase $75 \%$ menjadi $87,5 \%$ dengan kriteria sangat aktif/individual dan kriteria aktif untuk rata-rata keseluruhan siswa, untuk lebih jelas dapat dilihat

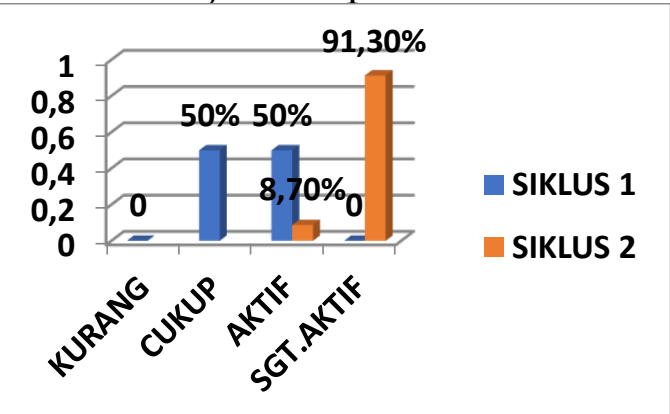

Grafik C.1. perbandingan observasi siswa siklus I dan II

Tabel dan grafik hasil observasi aktivitas siswa memperlihatkan perbandingan antara siklus I dan siklus II, pada siklus I rata-rata siswa yang sangat aktif dalam belajar mencapai $0 \%$ dan pada siklus II mencapai 91,30\%. Siswa yang aktif pada siklus I rata-ratanya mencapai $50 \%$ dan pada siklus II mencapai $8,70 \%$. Siswa yang cukup aktif pada siklus I rata-ratanya mencapai $50 \%$ dan pada siklus II mencapai 0\%. Siswa yang kurang aktif pada siklus I rataratanya mencapai $0 \%$ dan pada siklus II mencapai $0 \%$. 
Jurnal PTK dan Pendidikan

Vol. 7, No. 1, Januari - Juni 2021 (16-26)

Peningkatan aktivitas siswa dalam pembelajaran dipengaruhi oleh beberapa faktor, antara lain faktor yang berasal dari dalam dan faktor dari luar diri siswa. Permasalahan yang berasal dari siswa adalah kurangnya motivasi siswa untuk mengikuti pelajaran, Menurut Mc. Donald, motivasi adalah perubahan energi dalam diri seseorang yang ditandai dengan munculnya feeling dan didahului dengan tanggapan terhadap adanya tujuan(Rifai, 2016, hlm. 116). Motivasi dibagi menjadi dua(Latuconsina, 2014, hlm. 190) motivasi intristik (motivasi dari dalam diri) dan motivasi ekstrinsik (motivasi dari luar diri), motivasi intrinstik pada diri siswa dapat dipicu karena perintah atau imbauan oleh guru, maka dari itu guru harus pandai untuk memberikan motivasi kepada siswa agar agar pembelajaran dapat tercapai.

\section{Perbandingan Hasil Evaluasi Akhir Siswa Siklus I Dan II \\ Hasil evaluasi akhir siswa pada} siklus I dan siklus II yang diperoleh kemudian dimasukkan ke dalam tabel dan grafik, untuk lebih jelasnya dapat dilihat pada tabel dan grafik berikut:

\section{Tabel C.16 Perbandingan Nilai Evaluasi Akhir Siklus I dan Siklus II}

\begin{tabular}{lcccccc}
\multirow{2}{*}{ No Nilai } & \multicolumn{2}{c}{ Siklus I } & Nilai & \multicolumn{2}{c}{ Siklus II } \\
\cline { 2 - 7 } & & F & $\%$ & & F & $\%$ \\
\hline 1. & 100 & 0 & 0 & 100 & 1 & 8,3 \\
\hline 2. & 80 & 3 & 25 & 90 & 5 & 41,7 \\
\hline 3. & 70 & 3 & 25 & 80 & 5 & 41,7 \\
\hline 4. & 60 & 5 & $\begin{array}{c}41, \\
7\end{array}$ & 70 & 1 & 8,3 \\
\hline 5. & 50 & 1 & 8,3 & 60 & & \\
\hline Jumlah & 12 & 100 & Jumlah & 12 & 100 \\
\hline $\begin{array}{l}\text { Ketuntasan } \\
\text { individu }\end{array}$ & 66,7 & - & $\begin{array}{c}\text { Ketuntasan } \\
\text { individu }\end{array}$ & 85 & - \\
\hline $\begin{array}{l}\text { Ketuntasan } \\
\text { klasikal }\end{array}$ & - & $\begin{array}{c}66, \\
\text { Rata-rata }\end{array}$ & $\begin{array}{c}\text { Ketuntasan } \\
\text { klasikal }\end{array}$ & - & 85 \\
\hline
\end{tabular}

Syarifuddin, Nasrullah, Muhammad Syaiful

Tabel tersebut di atas menggambarkan ketuntasan individu dan ketuntasan klasikal pada siklus I dan II, pada siklus I siswa yang tuntas belajar ada 6 orang siswa dan ketuntasan klasikalnya mencapai $62,5 \%$. Pada pertemuan kedua siswa yang tuntas belajar 5 orang siswa dan ketuntasan belajar secara klasikal mencapai $72,5 \%$. Pertemuan pertama siklus II siswa yang tuntas belajar adalah 6 orang siswa dan ketuntasan belajar secara klasikalnya mencapai $75 \%$, sedangkan pada pertemuan kedua siswa yang tuntas belajar adalah 8 orang siswa dan ketuntasan belajar secara klasikal mencapai $100 \%$.

Nilai evaluasi akhir siswa dalam setiap kali pertemuan mengalami peningkatan, hal ini dipengaruhi oleh meningkatnya aktivitas siswa dalam mengikuti pembelajaran, sehingga siswa lebih termotivasi dalam belajar motivasi berguna untuk membangkitkan, meningkatkan serta memelihara semangat belajar siswa sebagaimana Ardan(Tune Sumar \& Abdul Razak, 2016, hlm. 197) mengatakan motivasi akan mempengaruhi seseorang dalam mengapai sesuatu, apabila motivasinya kuat maka akan kuat juga semangatnya sebaliknya apabila motivasinya lemah maka lemah juga semangatnya. Peningkatan motivasi belajar siswa sangat berpengaruh pada daya serap siswa terhadap materi yang disampaikan dalam pembelajaran, peningkatan motivasi belajar siswa dipengaruhi oleh penggunaan metode yang tepat dalam mengajar, karena metode pembelajaran memiliki beberapa manfaat sebagai berikut(Darmadi, 2017, hlm. 178-179): 1) membantu tercpainya pembelajaran, 
menyesuaikan situasi belajar dengan siswa; 3) mengefisienkan waktu pembelajaran

Penjabaran dari tabel hasil evaluasi akhir pada siklus I dan II kemudian dibuat ke dalam grafik ketuntasan belajar siswa secara individual dan grafik ketuntasan belajar siswa secara klasikal sebagai berikut:

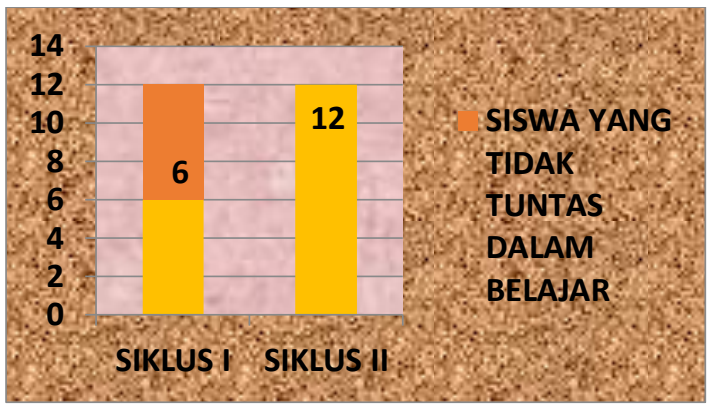

Grafik C.2. perbandingan

ketuntasan belajar siswa secara individual siklus I dan II

Dari grafik di atas dijelaskan sebagai berikut: pada siklus pertama siswa yang tuntas dalam belajar ada 6 orang sedangkan pada siklus kedua meningkat menjadi ada 12 orang atau 100\%. Dari hasil di atas maka pelaksanaan Penelitian Tindakan Kelas selama dua siklus di kelas III MIN 21 telah menjawab hipotesis yang dibuat bahwa jika pembelajaran membaca dengan menerapkan metode gerak mata pada mata pelajaran Bahasa Indonesia, maka hasil belajar siswa dalam membaca cepat akan meningkat, hal ini dapat dilihat pada hasil observasi yang telah dilakukan. Dalam setiap kali pertemuan selalu menunjukkan peningkatan yang signifikan baik observasi terhadap kegiatan guru, aktivitas siswa maupun hasil kerja siswa.

\section{KESIMPULAN}

Berdasarkan hasil Penelitian Tindakan Kelas siklus I dan siklus II, yang telah dilakukan di MIN 21 kelas III mendapatkan temuan sebagai berikut:

a. Terdapat peningkatan aktivitas guru dalam pembelajaran membaca huruf hijaiyah menggunakan kartu tukar huruf dengan skor 31 dengan kriteria cukup baik menjadi 58 dengan kriteria sangat baik dengan skor 58.

b. Terdapat peningkatan hasil aktivitas siswa dalam pembelajaran membaca huruf hijaiyah dengan media kartu tukar huruf terbukti dengan meningkatnya kemampuan baca siswa di mana pada siklus aktivitas siswa mendapat skor 120 dengan kriteria cukup aktif meningkat pada siklus ke II menjadi 206 dengan kriteria sangat aktif

c. Terdapat peningkatan hasil belajar siswa pada siklus I dengan kriteria tidak tuntas karena mendapatkan skor 66,7 dan Siklus ke 2 dengan skor 85 dengan kriteria Tuntas

\section{Daftar Pustaka}

Afifuddin, M. (2017). Peran Guru dalam Menciptakan Keteraturan Pembelajaran - Kompasiana.com. https://www.kompasiana.co $\mathrm{m} /$ afifuddin_afandi/59d568c3 096dea46394911e3/peranguru-dalam-meciptakanketeraturan-pembelajaran

Ansori, M. (2007). Penelitian Tindakan Kelas. CV. Wacana Prima.

Arsyad, Azhar. (2003). Bahasa Arab dan Metode Pengajarannya. Pustaka Pelajar. 
Jurnal PTK dan Pendidikan

Vol. 7, No. 1, Januari - Juni 2021 (16-26)

Arsyad, Azhari. (2005). Media Pembelajaran Pembelajaran. PT. Raja Grafindo Persada.

Darmadi. (2017). Pengembangan Model dan Metode Pembelajaran dalam Dinamika Belajar Siswa. Deepublish.

Eko Yulianto, I. (t.t.). Antara BelajarMengajar - Pembelajaran -

Kompasiana.com. Diambil 25 Februari 2020, dari https://www.kompasiana.co $\mathrm{m} /$ ipnuekoyulianto/550d7393 a333111b1b2e3c2b/antarabelajar-mengajar-pembelajaran

Gintings, A. (2010). Esensi Praktis Belajar $\mathcal{E}$ Pembelajaran: Disiapkan untuk Pendidikan Profesi dan Sertifikasi GuruDosen. Humaniora Utama Press.

Hamalik, O. (2008). Perencanaan Pengajaran Berdasarkan Pendekatan Sistem. Bumi Aksara.

Latuconsina, H. (2014). Pendidikan Kreatif: Menuju Generasi Kreatif $\mathcal{E}$ Kemajuan Ekonomi. Gramedia Pustaka Utama.

Mulyasa, E. (2009). Implementasi Kurikulum Tingkat Satuan Pendidikan, Kemandirian Guru dan Kepala Sekolah. PT Bumi Aksara.

Nulyati, T. (2011). Bahasa Indonesia. Universitas terbuka.

Rifai. (2016). Penelitian Tindakan Kelas PAK: Classroom Action Research in Christian Class. Bornwin's Pubilishing.

Syarbini, A., \& Mufidah, A. (2010). 5 Langkah Lancar Membaca AlQur'an. Ruang Kata.

Syarifuddin. (2017). Visi misi dan
Syarifuddin, Nasrullah, Muhammad Syaiful

kompetensi pedagogik guru kelas: Studi multi kasus di Sekolah Dasar Islam Terpadu (SDIT) Ihsanul Amal Amuntai Kalimantan Selatan dan di Madrasah Ibtidaiyah Negeri (MIN) Model Amuntai Kalimantan Selatan [PhD Thesis, Universitas Islam Negeri Maulana Malik Ibrahim]. http:/ / etheses.uinmalang.ac.id/9927/

Syarifuddin. (2019). Meningkatkan Hasil Belajar Peserta Didik pada Mata Pelajaran IPS Menggunakan Model Pembelajaran Picture and Picture. https://journal.iainsamarinda.ac.id/index.php/SAJIE/ article/view/1657/pdf, 2(1), 5166. https://journal.iainsamarinda.ac.id/index.php/S AJIE/issue/archive.

Tafsir, A. (2008). Metodologi Pengajaran Agama Islam. PT. Remaja Rosdakarya. Tim pengembang Ilmu Pendidikan Bagian II. (2007). Ilmu dan aplikasi pendidikan. PT Imperial Bhakti Utama.

Trianto. (2011). Panduan Lengkap Penelitian Tindakan Kelas. Prestasi Pustakarya.

Tune Sumar, W., \& Abdul Razak, I. (2016). Strategi Pembelajaran dalam Implementasi Kurikulum Berbasis Soft Skill. Deepublish.

Zaman, B., Heri Hermawan, A., \& Eliyawati, C. (2008). Media Dan Sumber Belajar TK. Universitas Terbuka.

Zulela. (2012). Pembelajaran Bahasa Indonesia Apresiasi Sastra di Sekolah Dasar. PT Remaja Rosdakarya. 
Jurnal PTK dan Pendidikan

Vol. 7, No. 1, Januari - Juni 2021 (16-26)
Syarifuddin, Nasrullah, Muhammad Syaiful 